\title{
التضشينات السيكولوجية في الفيلم الروائي المعاصر
}

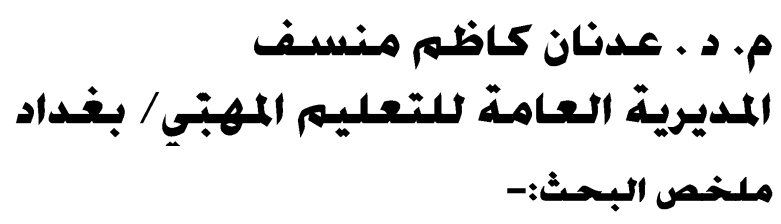

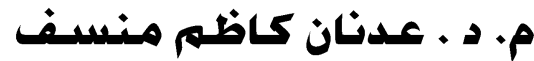

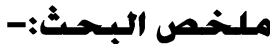

اشتمل البحث على اريع فصول: جاء الفصل الاول تحتوي على مثكلة البحث الذي تمثل بالسؤال التالي: كيف تثتنظل التضمينات السايكولوجية في الفلم الروائي المعاصر؟ وهدف البحث في اشتغال التضمينات السايكولوجية في الفصل المعاصر وكذلك الحدود الثثلاثة للبحث. و احتوى الفصل الثاني الاطار النظري الى ثلاث ما حث تضمن المجث الاول مدخل لفهم التضمين السـايكولوجي. امسا المبحث الثاني تنـاول بنية الفيلم الروائي المعاصر و المبحث الثالث تناول اليات اشتغال التضمينات السايكولوجية في بنية الفيلم الروائي المعاصر؟ والفئل الفصل الثالث احتوى على اجراءات البحث و تحليل عينة البحث ـ اما الفصل الرابع فقد تضمن النتائج والاستنتاجات المقترحات: ثم اختم البحث بالمصادر Abstract:

The study included four chapters: The first chapter contains the problem of research, which is represented by the following question: How do psychological implications work in the contemporary novel?

The purpose of the research is to engage in psychological implications in contemporary classroom as well as the three boundaries of research.

The second chapter contained the theoretical framework to three, urging the first module to provide an introduction to understanding the psychological inclusion.

The second section deals with the structure of the contemporary novel

And the third topic, how to deal with the mechanisms of psychological implication in the structure of the contemporary novel?

The third chapter included research procedures and analysis of the research sample. The fourth chapter included the results and the conclusions of the proposals: Then conclude the search by sources

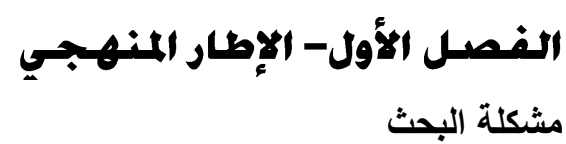

تجاورت السينما مع الكثير من الحقول المعرفية والبنى ذات المنحى العلمي والانساني و اصبح هنالك علاقة من

التأثر والتأثير فيما بين هذه المفاهيم و الأفكار المعرفية وبين السينما على الرغم من اختلاف الوسط التعبيري لكل منها ، و من هذه البني المعرفية المتجاورة مـع السينما هو علم النفس الذي اثتقت منه السينما الكثير من الأفكار و المعلومـات و التضمينات السـايكولوجية التي اشتخلت وبفاعلية في البنيـة التركيبية للفيلم لاسيما المعاصـر منـه الذي ينسـم بنوع من التركيب المفـارق نو عـا مـا للأفلام والخطابـات السينمائية الكلاسيكية التي لا زالت تعتمد وبشكل رئيسي على المنطق و البنـاء الأرسطي ، وقد تعددت وتتو عت التضـمينات السـايكولوجية صـورية وصـونية و المشـتقة بالارجـة الأسـاس مـن الأفكار و المفـاهيم المتو افرة في علم النفس كمبأدى عامـة و العامل في الفيلم، وتباينت الاشتغالات البنيويـة في الفضـاء الصوري الذي يخلقه فن الفيلم وبغية أضاءة هذه التضمينات السـايكولوجية وطبيعـة أدائها في الفيلم المعاصـر نهض هذا البحث المعنون ((التضمينات السايكولوجية في الفيلم الروائي المعاصـر)) الذي صـاغ مشكلة بحثه وفق التسـاؤل الاتـي: كيف تشتغل التضمينات السايكولوجية في الفيلم الروائي المعاصر؟ 
أهمية البحث

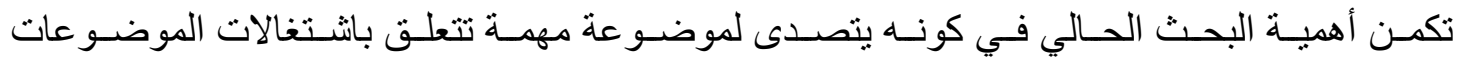

السايكولوجية في بنية الفيلم المعاصر

أهداف البحث

يهدف للكثف عن كفيات اشتعال التضمينات السايكولوجية في الفلم المعاصر.

حدود البحث

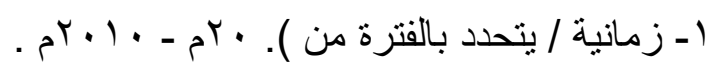

r- ب انية / الو لايات المتحدة الامريكية .

ب- موضو عية / يتحدد بدر اسة موضو عة أثتغالات التضمينات السايكولوجية في الفيلم الروائي المعاصر .

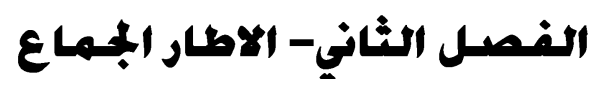

المبحث الأول / مدخل لفهم التضمين السايكولوجي

كثيرة هي العلاقـات التي نجدها متضـمنة في الأفلام السينمائية فهنالك علاقـات فلسفية نجد صداها

و تأثثير اتها و اضحة في بنية العمل الفني السينمائي و هناللك علاقات اجتماعيـة وفكريـة ودينية وكذلك ايضـا نجد علاقات او ثيمات سايكولوجية متضمنة في ثنايا الفيلم سواء على مستوى عناصره البنائية ام على مستوى الفيلم ككل وربما يمكننا القول ان اي فيلم لا بد وان يتضمن صر اعات وانفعالات وحالات شعورية ووجدانية ولحظات من الفرح و الألم و الحزن و البكاء و غير ها من الظو اهر التي تتعلق بشكل وثتيق بحياة الثخصيات الدر اميـة وهذه جميعا موضـو عات سـايكولوجية مضـنة في موجودات الفيلم السينمائي، وربمـا ايضـا يمكنتـا القول بـان هذهـ الظو اهر السايكولوجية كلما ازدادت في الفيلم كلما كان اكثر اقتراب من مفهوم الفيلم السـايكولوجي وازداد تأثيره في مشاهديه سلب ام ايجابا وحتى ان الكثير من نظريات الفن تتحي هذا المنحى السـايكولوجي في تعريف الفن

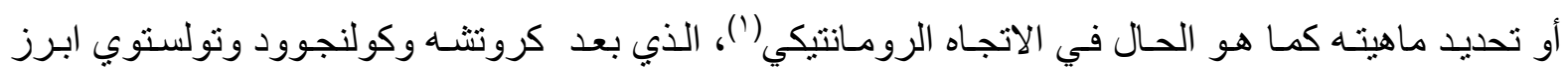
فلاسفته ومنظريه حيث يؤكد هذا الاتجاه على أن الفن ( ايا كان نوعه ) هو تعبير عن انفعالات الفنان او صـانع العمل و الذي يجتهـ مـن اجل ايصـال هذه الانفعـالات الـى المتلقين و هناللك العديد مـن المفـاهيم او النظريـات السايكولوجية التي نجدها تعمل في الفضـاء الدر امي للفيلم سواء بشكل واضـح وصريح ام بشكل مضمن ويتم استتتاجها ذهنيـة من قبل المشـاهدين وحسب قدرتهم التأويليـة ومستوى ثقافتهم ومرجعياتهم الفكريـة ومن هذه النظريـات في مدرسـة التحليل النفسي التي اوجدها سيغموند فرويد التي تنـير الى غريزة الحياة في جانبها الجنسي و المـرتبط باللذة وكيفيـات اثـباعها وهنالك خمس عمليـات ـ كمـا يقول المحللون النفسيون المهتمون بالسينما - تؤدي دورها في تحويل الثخص العادي الى تكوين خاص هو المشاهد للسينما هي (؟):

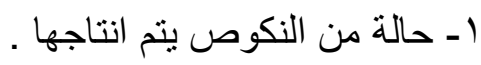

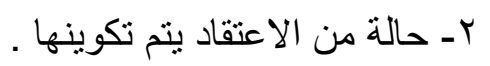


r- ميكانزمات التوحد الأولية التي يتم تنشيطها .

ـ ـ البنيات التخيلية مثل المشاعر الرومانسية العائلية التي تستثار بوساطة الحكايات الخيالية . هـ علامات التلفظ او النطق التي تطبع الفيلم بطابع التأليف او النسبة المؤلف معين ، وهذه ينبغي اخفائها . ومما يجب الانتباه اليه في هذه العمليات الخمسة الخاصة بالاشتغالات و التمثلات السايكولوجية في بنائية الفيلم السينمائي الى انها تتجه وتتحرك في مفصل رئيسي مهم في الفيلم الا وهو موضوع الثخصية الدراميـة و علاقاتها الباطنيـة والخارجيـة وطبيعـة صـر اعاتها مـع البيئة او المحبط و الثخصيات الدراميـة الأخرى وربمـا

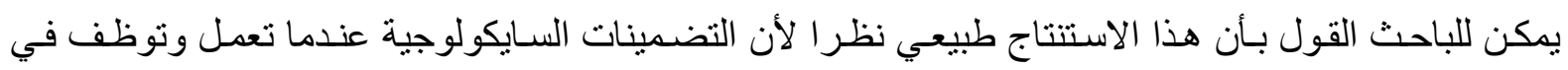
العمل الفني لاسيما السينمائي لابـد وان تتجه وتتموضـع في تركيب الثخصيات الدر اميـة لان علم النفس بشكل عام يدرس السلوك البشري والحالات السايكولوجية للافراد سواء كانوا فنانين ام اشخاص من الو اقع الفيزيائي ، لذا فان الباحث سيقوم باير اد او تقسيم بضعه احد الباحثنين لمكونات الثخصية بشكل عام والذي يمكن أن بتناسب

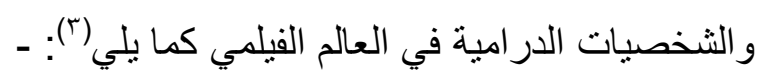
I- المكون الجسمي ويتضمن الجانب البايولوجي و الفسيولوجي و العضوي بشكل عام . r - المكون العقلي ويتضمن العمليات العقلية مثل التفكير و الادر الك والتعلم .

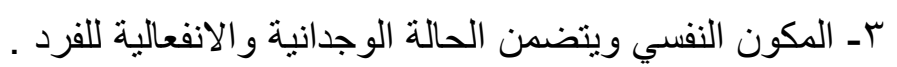

عـ المكون الاجتماعي ويتضمن التعلمات والخبرات التي اكتسبها الفرد في المجتمع الذي يعيش فيه. و هذا التقسيم العلمي الأكاديمي يقترب من التقسيم الثنائع في الوسط الفني ومتداول در اميـة في المسرح و التلفزيون و السينما و هو التقسيم المعتمد على الأبعاد الثلاث للثخصية بشكل عام او للشخصية بشكل خاص

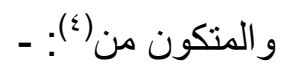

$$
\begin{aligned}
& \text { 1 - البعد الجسماني(الطبيعي) . } \\
& \text { r- البعد النفسي . البعد } \\
& \text { rـ البعد الاجتماعي . البعي . }
\end{aligned}
$$

ويمكن ملاحظة أن ((المشاهد للسينما هو مشاهد راغب او مملوء بالر غبات وحالة المشـاهدة التي تكون هذا المشاهد ،وكذلك نص الفيلم نفسه ينظر اليهما باعتبار هما يحركان بنيان التخيل اللاشعوري وتكون السينما هنـا - بشـكل يفـوق أي شـكل اخـر - قـادرة فعـلا على اعـادة أنتـاج او الاقتـر اب مـن بنيــة او منطـق الاحـلام

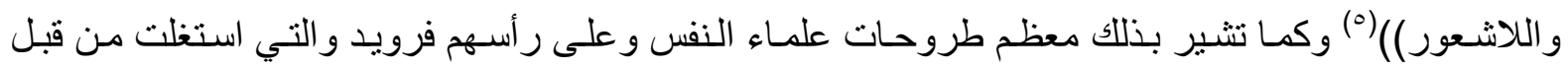
السينمائيين وافادوا منها في تضمين افلامهم هذه الافكار والمفاهيم السـايكولوجية بوصفها مرتكزات ذات بعد وهد علمي ورصانة منطقية تزيد من تماسك البناء العضوي للافلام السينمائية لاسيما في جانبها السايكولوجي . المبحث الثاني- بنية الفيلم الروائي والسايكولجي المعاصر إن بدايات السينما كانت عبارة عن أفلام وثائقية تقليدية ذات بنـاء فكري أو صوري أو مفاهيمي بسيط وربما يمكننا القول لأن البناء فيها كان اعتباطيا وغير مدروس لكن مع ذلك فهي امتلكت نوعـا من البناء وقد 
استمرت الأفلام السينمائية لفترة ليست طويلة على هذه الثـاكلة وهذا النمط الوثائقي البسيط حتى جاء بعض المجدين أمثال البريطاني اسميث الذي أضاف اللقطة الكبيرة (Close up) ومن ثم جاء بورتر و أسلوبه الجديد في سرد القصة والمونتاج في فيلمه الثهير (سرقة القطار الكبرى) وحدثت الانعطافة الكبرى في مجرى السينما مع إسهامات (غريفث) وفيلمية الثهيرين (مولد أمة) و (تعصب)(T) ، حيث أحدث نقلة كبرى على مفهوم البناء

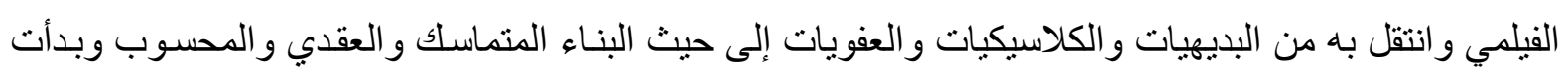

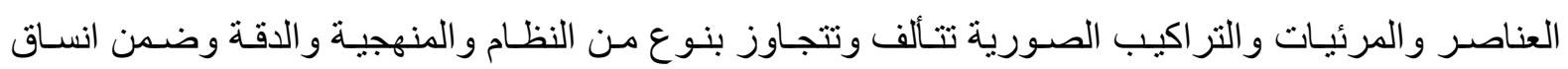

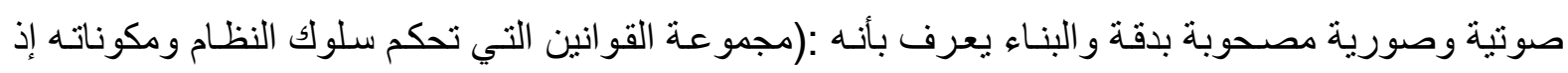
يمكن أن تحل أحدهما محل الأخرى)(") . و إذا مـا تطرقنا إلى المسـار التـاريخي الذي مر بـه البنـاء الفيلمي منذ بداياته الأولى مـع أفلام الأخوة

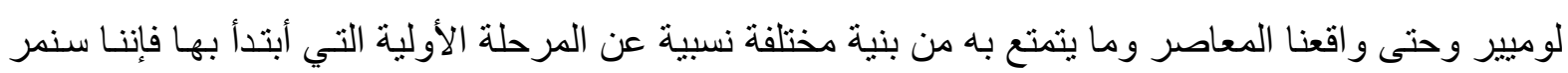

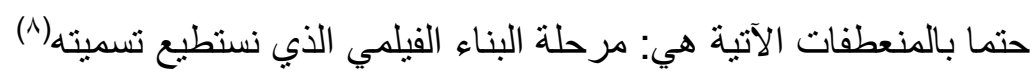

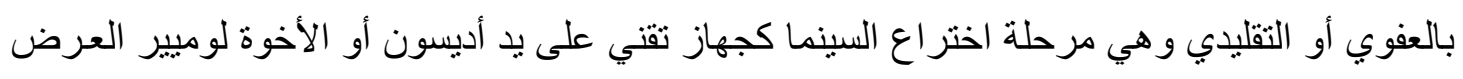
صور مرئية متحركة على شاشة بيضاء وهنا كان البناء الفيلمي بسيطة وربما غير مقصود ولكنه مع ذلك يمتلك هيك سمات البناء الفيلمي ثم تطور بشكل مذهل مع جريفث الذي بطلق عليه أحيانـا مجدد السينما و الذي كان بارعة

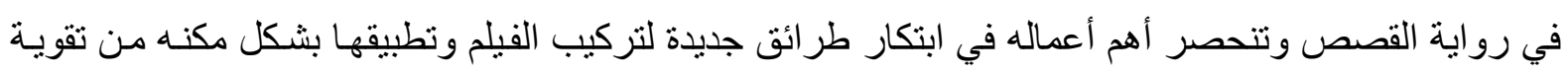
سرد القصة عن طريق السينما) (9). وساهمت المدرسة التعبيرية الألمانية في عشرينيات القرن المنصرم في إضافة نوعية للبناء الفيلمي من خلال بعض الأفلام المميزة مثل(عيادة الدكتور كاليكاري) التي قدمت شكلا ومضمونة مختلفة للبناء الفيلمي و اعتمادها على تقنية الضوء و الظل و الديكورات و التركيبات الغريبة نو عا ما فضلا عن بعض التقنيات الأخرى. وأضافت المدرسة السينمائية الروسية منمثلة بأبرز روادها ايزنشتاين وبودوفكين ولوكيشوف و غير هم اسـهامات لا غنى عنها في التركيب الفيلمي والبناء العضوي للفيلم والذي ابتعد بمسـافات واضحة عن البناء التقليدي الذي سبقه وكان لعنصر المونتاج الدور المفصلي والأساس في هذا التركيب الجديد والذي أعطى نتائجه المثمرة على ولى ولى ولى صعيد البناء الفيلمي حيث اكتسب الفيلم آنذاك شكلا جديدة وبنـاءة مميز او غير مسبوق قائم على مبدأ الجدل و الفكر و الصر اع والتجاور غير الاعتباطي للأنساق والأجز اء و التي تحتم انتظام سببي للقطات والمشاهد الفيلمية

ضمن بناء فيلمي محسوب ودقيق.

ثم جاءت فترة نهاية العشرينات وبداية الثلاثينيات من القرن الماضي لتشهد تبدلا جديدا على شكل البناء الفيلمي و أيضا على مضمونه بسبب دخول الصوت ضمن البنية الجديدة لمنظومـة الفيلم ثم دخول الألوان فضـلا

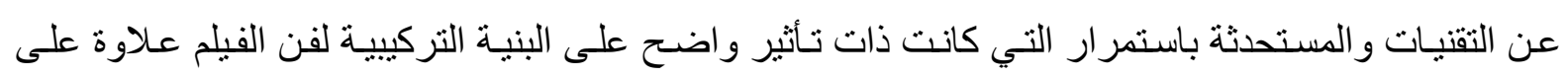


التطـور المستـمر في التقافـة السـينمائية والـوعي السـينمائي عند طرفي العمليـة التفاعليـة الإبداعيـة للخطـاب السينمائي (المرسل و المستقبل) أي بين صانع الفيلم ومتلقيه .

وبعد ذلك أدخل مجموعة من المخرجين المهمين في تاريخ السينما العالمية أمثال (هيتشكوك و أوسون ويلز وايليا كاز ان) ورواد الواقعية الإيطالية مثل فيسكونتي ودي سبكا وروسوليني وغيرهم فضـلا عن جماعة

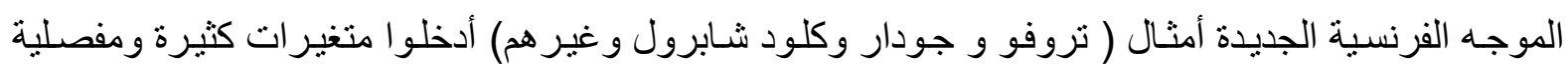
على البيئة التركيبية للفيلم وانتقل الاشتغال من المونتاج وجمالياته ونأثير اته البنائية على التركيب العام للفيلم إلى ولى جماليات الاشتخال في عمق الميدان والتكوين و الميز انسين داخل الكادر مـع حتم إجراء تعديلات على البناء الفيلمي لتنتلائم وهذه المستحدثات على مستوى الوعي والفهم النظري لفن الفيلم أو على مستوى التطبيقـات العملية للأفلام.

ثم جاءت الأنو اع السينمائية المتعددة كأفلام الغرب الأميركي(الويسترن) و أفلام الأكثن و الخيال العلمي

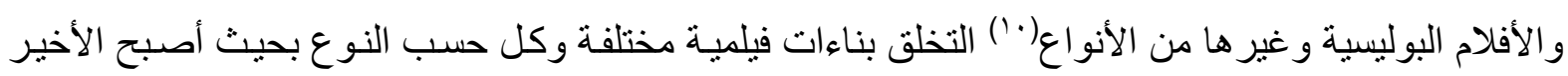
هو صاحب التأثير الأكبر في البيئة الفيلميـة ومـا تستلزمه من اشتر اطات وقو اعد تركيبيـة لبنـاء الفيلم في شكله

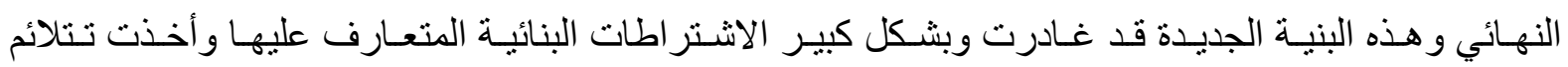
ومتطلبات الجمهور الحديث و المعاصر ومـع كل ذلك الابتعاد والتغير إلا أنها لم تكن مغايرة بـالمطلق للشكل المتعارف عليه للبنية الكلاسيكية للأفلام السينمائية ذلك لأنها تعتمد وبشكل أسـاس على نفس مجموعة العناصر و التركيبات و المرئيات التي تتكل العمود الفقري لأي فيلم سينمائي سواء كان معاصرة أم قديما نسبية وكان لاخول التقنيات الرقية في صناعة الفيلم المعاصر دورا واضحا في تشكيل بناء فيلمي مختلف عما سبقه لأنها سهلت الكثير من التفاصيل والمستلزمات و الآليات التي كانت تعيق ربما عملية التغيير في البناء الثكلي للأفلام فضلا عن تكاليفها غير الباهظة وسهولة توظيفها سينمائية في بيئة الفيلم المعاصر علاوة على اختصسار الكثير من الوقت و الجهر و عليه يمكن القول بأن البناء الفيلمي هو ليس مجرد تقنية توظف أو يتم الاعتمـاد عليها بشكل

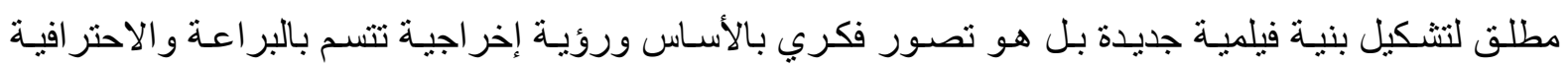
و التجدد(')( تتمثل أسس البناء الفيلمي أيضا في توظيف عناصر اللغة السينمائية من قبل المخرج وبطريقته هو فئه ، فيبدع بتوظيف الإضـاءة أو حركة كامير أو المونتاج ....التخ و إن البنـاء الفيلمي في حقيقة الأمر إنما توحيد لتركيبة واسعة من البني الأخرى(السرد ، الإدر اك السمعي و البصري و المؤثرات واندماج هذه البني أو تعاقبها أو احلال واحدة مكان الأخرى هو الذي يقيم البناء الفيلمي بصورته النهائية) .. و لا بد في الختام من التطرق إلى التى البنية الفيلمية المتوافرة في الأفلام عن البني التقليدية التي دأبت على الاشتغال ضمن أنماطها الأفلام السينمائية

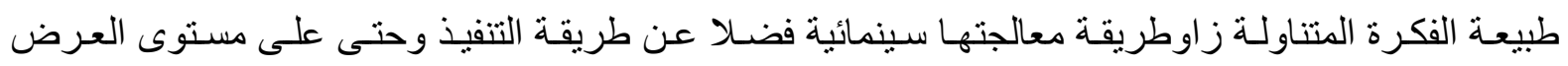
السينمائي من حيث تقتية العرض وطريقته أو مكانه أو في الطقوس التي عادة ما ترافق الأفلام التجريبيـة والتي غالبا ما يتم عرضها في المنتديات السينمائية ونو ادي السينما و المهرجانات ولبيت في قاعات العرض السينمائي الاعتيادية ، كما لا بد من الإشارة ونحن نتحدث عن البنية الفيلمية للأفلام المعاصرة نشير إلى البناء الفيلمي في 
أفلام موجة سينما الدو غما حيث الوصـايا العشر التي أعتمدها مخرجوا تلكك الموجة و التي أثرت بدور ها على طبيعة البناء الفيلمي بسبب الاشتر اطات التي تفرضها هذه القواعد وبسبب طبيعة التقلي المعاصر التي عادة مـا تفرض اشتر اطاتها ورغباتها وطلباتها على طبيعـة الانتاج السينمائي العـالمي لكون الأخير يعتمد بشكل يكاد يكون مطلق على شباك التذاكر وعلى الإير ادات التي تأتي منـه لدعم صناعة السينما والاستمر ار بإنتاج وتنفيذ الأفلام السينمائية.

المبحث الثالث ـ آليات اشتغال التضمينات السايكولوجية في بنية الفيلم الروائي المعاص

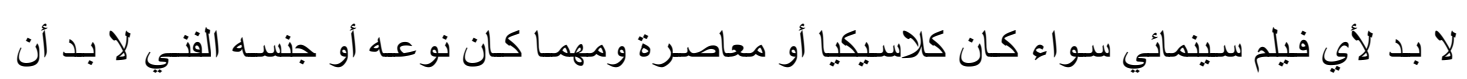
يتضمن ويحتوي على تضمينات سـايكولوجية عديدة وربما لا تكون واضحة المعالم أو يمكن التقاطها بسهولة ولكنه بالتأكيد سيتضمن بعضا من تلك التضمينات التي هي عبارة عن أفكار أو مفاهيم أو مقو لات أو اشتغالات

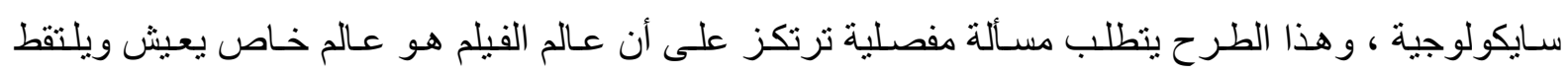
ويستمد ديموته من عملية التلقي التي قوم بها المتلقي الذي هو عبارة عن مجموعة من الأحاسيس و المشـاعر و التصور وات النفسية التي يشعر بهاو هو يتلقى أو يشاهد فيلما سينمائية ومن ثم فإن عملية المشـاهدة والتلقي هي هي هي عملية سايكولوجية بالدرجة الأساس فضلا عن الجوانب الأخرى كالجانب العقلي و الفلسفي و الحسي المتضمن في عملية المشاهدة الفيلمية وطقوس تلقي أي خطاب سينمائي ويقول جان ميتري (تتمثل فضيلة تركيب الفيلم في أن انفعال و عقل المشاهد يندرجان في سياق التطور الإبداعي والمشاهد ير غم على أن يتبع الطريق التي سلكها المؤلف في بناء للصورة، هي أعلى درجـة تقريب ممكنة لنقل الفكرة وشعور المؤلف الى المشـاهد في كمالها

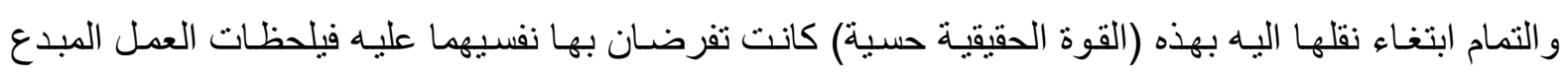
والرؤيسة الخلاقـة)(r') مثنل عنصـر الشخصية الدراسية وكذلك الزمـان والمكان والموسيقى والحسوار و الحركة و التكوين و المؤثرات بشقيها الصورية والصوتية وغير ها من العناصر التي سنتناولها بشيء من التفصيل وكما يلي:-

أولا : الثخصية الدرايهية:-

تعد الثخصية من أحد المقومات الأساسية لأي فيلم سينمائي ورغم وجود بعض الأفلام السينمائية التي لا وجود للشخصية الدراسية فيها كما هو الحسال في بعض الأفلام التجرييية إلا أنه يمكن القول بأن لا يمكن الحصول على نأثثر كبير في جمهور المشاهدين دون وجود شخصيات دراسية تتحرك وتتفاعل وتتصسار ع فيما بينها داخل بنيـة الفيلم السينمائي وبذات الوقت فهي تحساول ـ أي الثخصيات الدر اسية ـ أن تنقل صـر اعاتها ومشـاعر ها و أفكار هـا إلى جمهورهـا المتلقي للعرض الصـوري وبالتـالي ضمان مشـاركته في اللعبـة البصرية المعروضة على شاثة سينمائية . ثنانية الحوار:

و هذا العنصر يحمل قيمة مهمة في البناء التركيبي للفيلم السينمائي كونـه الحامل لدلالات الفيلم الفكريـة و المعبر عن آراءه وطروحاته وهو يرتبط جدلية بالثخصية الدرامية إرنباطا وثيقا كونه ينبثق عنها ويدل عليها

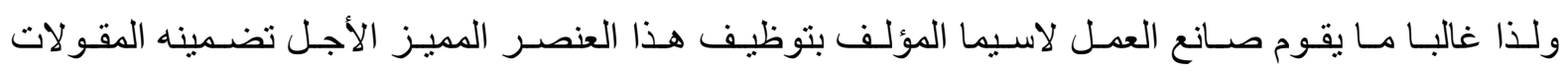


السـايكولوجية التـي تريـد إيصـالها إلى جمهور المتلقين وهذه تعد احدى ابرز صـور الإيصـال كونها مباثـرة وو اضحة و لا تشتغل على المعاني الباطنية التي يتم استخر اجها بشكل ضمني أو استقرائي من قبل المتلقين ، بـل

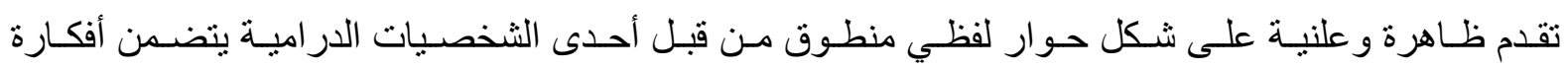
سايكولوجية معينة وو اضحة وكما شـاهدنا في فيلم (تحت رمال بابل)(*')للمخرج العر اقي ححم الدر اجي حيث نرى في أحد المشاهد الثخصية الدر امية (سيد كاظم) وهي تخبر السائل (المخرج نفسه ولكن من خـارج الكادر)

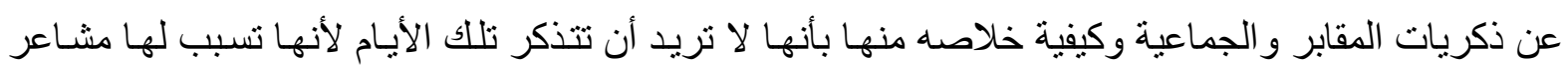
نفسية مؤلمة وحزينة والحوار غالبا ما يعكس طبيعة الثخصية الدرامية وأر هاصاتها السايكولوجية كما أنه يعبر

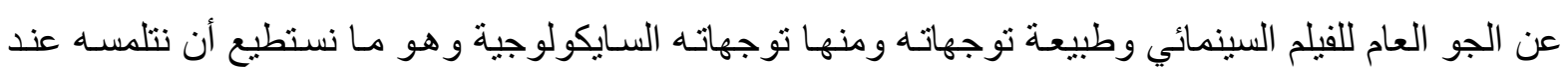

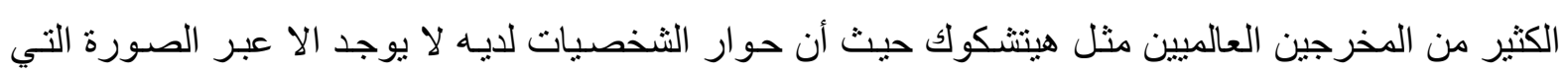

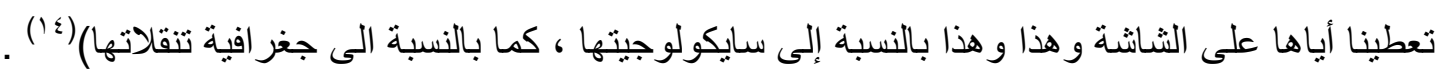
ثنالثا الزمان:-

تكمن أهمية هذا العنصر في بنائية الفيلم السينمائي بكونه الحاضنة الزمنية للأحداث والأفعال التي تقوم

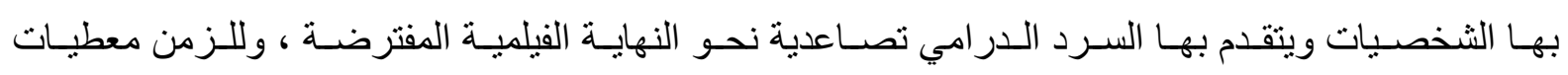
سايكولوجية بارزة ومهمة فهو ربمـا يرتبط بالماضـي وذكرياته أو بالحاضر وتفصيلاته المتعددة وربمـا يرتبط

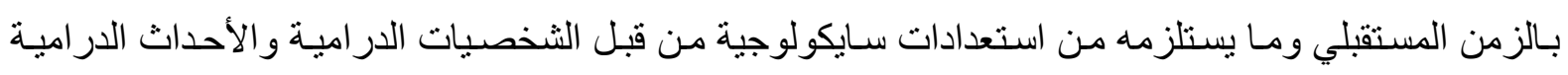
لأجل التهيئة والإعداد لبناء معطيات سايكولوجية تتلائم وطبيعة الحدث المستقبلي . كما أن التقسيم الثلاثي الذي أقترحه بيلا بالاش للزمن يتضمن مرتكز أساسية وهو الزمن النفسي والذي

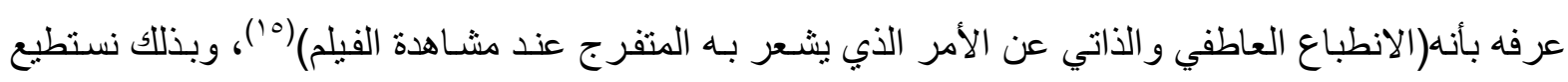
أن تلمس أهمية الزمن بالنسبة للنضمينات السايكولوجية المتوافرة في بنيـة الفيلم السينمائي أي أن المتلقي أحيانـا قد ينظر للفيلم بوصفه ظاهرة نفسية ويتلقى الفيلم من الناحية السايكلوجية ليس باعتباره شريطة صورية يعرض

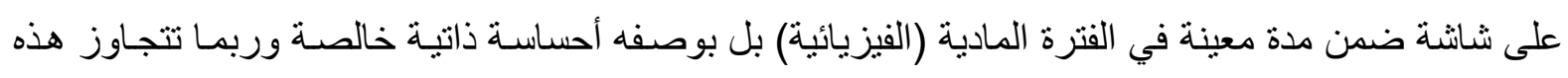
الحالة الشعورية السايكولوجية زمن الفيلم ذات الطابع السايكولوجي البطئ الإيقاع و الحركة وبين أفلام الأكثن

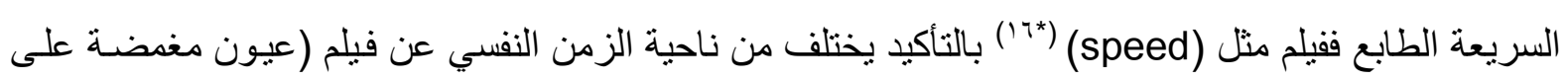

$$
\begin{aligned}
& \text { إتساعها) الستانلي كوبرييك. } \\
& \text { رابعا: المكان }
\end{aligned}
$$

هنالك دائما سواء في الواقع الفيزيائي أو في عالم الفيلم السينمائي هنالك علاقة مـا بين المكان و المظاهر السايكولوجية وييدو بأنهما يشتركان مع بعض في انتاج أو توليد معان و أفكار ذات أهمية واضحة و هو مـا يتبدي بشكل كبير في بنية الفيلم السينمائي إنطلاقا من بديهية أن المكان هو و عاء واسع لتجري ضدمن حدوده الأحداث الدر امية فضلا عن أنه يشكل أرضية ومرتكزات أساسية تقوم عليها الكثير من الموضو عات الفيلمية التي تستند

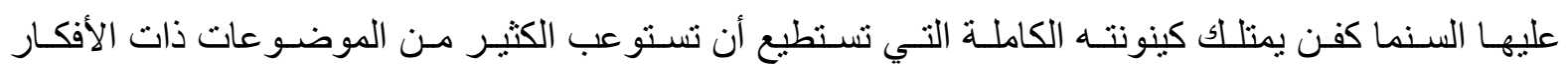


السـايكولوجية وتضمينها في بناءهـا الداخلي لاسيما تلكك الموضو عات المتعلقة بالمكان حيث (تستبدل السينما العنصر المكاني السينمائي بالعنصر المكاني التصويري، وبهذه الحيلة تحتوي العنصر المكاني التصويري داخل المكان الطبيعي اللامحدود الذي ترينا إياه الكاميرا عادة ويوضح هذا الطبيعـة الاعتباطية لمفهومنـا عن العنصر

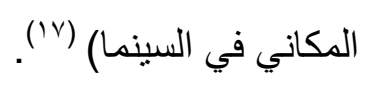

و هذه الآلية في التحويل والتغيير في عنصر المكان فيزيائية وسينمائية تمنلك فوصيات سـايكولوجية مضمنة أو ظاهرة في ثنايا الخطاب السينمائي وكما شـاهدنا ذلك في الكثير من الأفلام السينمائية كما في فيلم

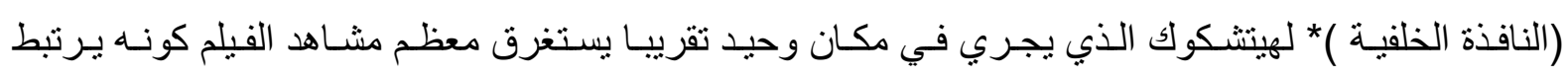

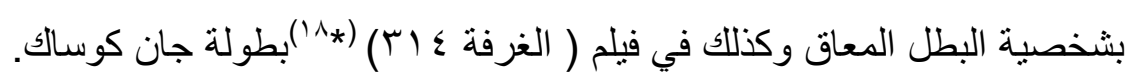
خامسا : الحركة

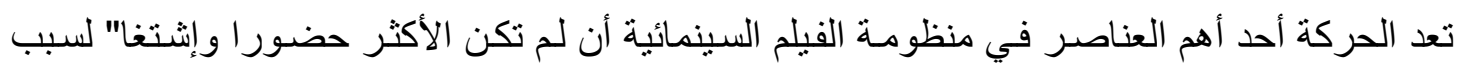
بسيطو هو أن معظم العناصر الأخرى تتضمن عنصر الحركة سواء كانت حركة موضعية أمحركة انتقالية وللحركة عدة تتويعات داخل بنية الفيلم ومنها (19):

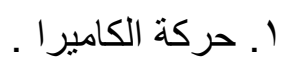

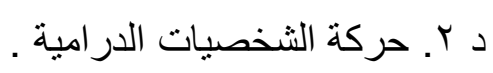

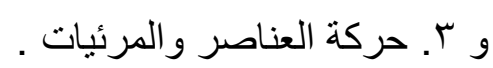

$$
\begin{aligned}
& \text { ع. حركة الأحداث ونموها در امية نحو الذروة . } \\
& \text { ه. حركة اللقطات و المشاهد مونتاجية . }
\end{aligned}
$$

و هذه الأنو اع من الحركات ربما تتداخل مع بعضها البعض أو تظهر منفردة الاشتغال داخل بنائية الفيلم

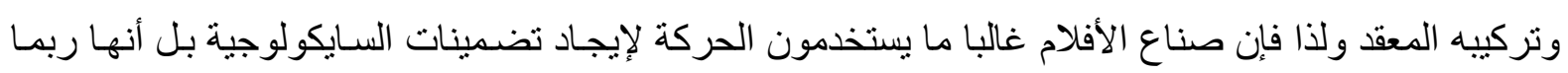

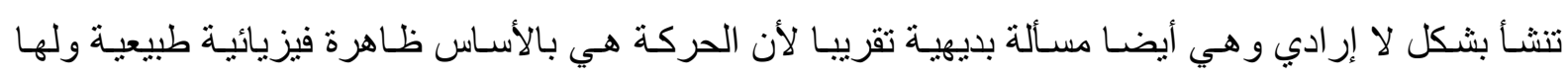
مبرر اتها ونتائجها ربمـا ترتبط بالجانب السـايكولوجي سواء من ناحية صـانع العمل أو من ناحيـة متلقي الفيلم وكذلك فهي ترتبط أيضا بالنوع الفيلمي حيث (أن الأفلام الملحمية و السايكولوجية تستخدم الحركة بطرق مختلفة

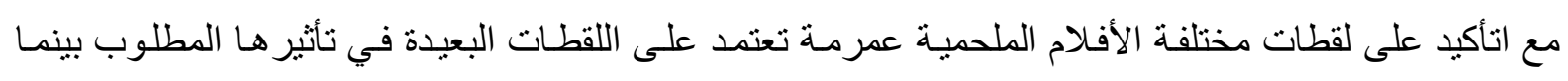

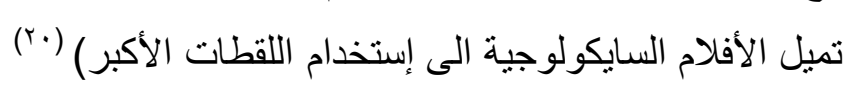

$$
\text { سادسا : الموسيقى }
$$

للمجرى الصوني بشكل عام تأثثر و اضح المعالم في مسنتوى تركيب الفيلم السينمائي نظر ا لما يمتلكه من عناصر فاعلة ومؤثرة در امية وسايكولوجية كالحوار و الموسيقى والمؤثرات وحتى الصمت وتمثل الموسيقى

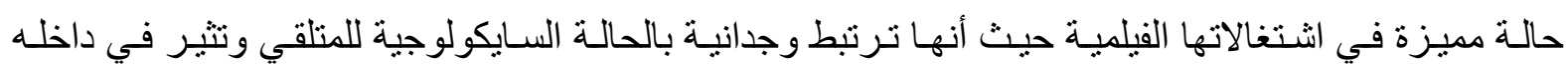

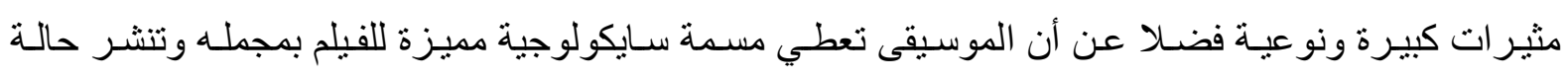
عاطفية شديدة الارتباط بالجانب النفسي لمشاهدي الفيلم وهو مـا يجعل بعض الموسيقيين وكذلك صناع الأفلام 
يتباينون في زاوية رؤيتهم السايكلوجية في استخدام الموسيقى في الفيلم كون أنها قد تسرق الأنظار عن الصورة الفيلمية أو أحيانا العكس ولذلك ( أثتنكي الكثير من الموسيقيين بأن الصور تميل الى سلب الموسيقى من جمالها و غموضها وذللك لأن المرئيات لديها وسيلة لجذب الأنظام الموسيقية نحو أفكار و عواطف محددة ، و على سبيل

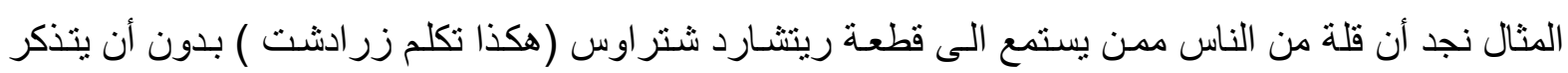

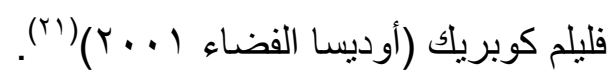

و هذه الإشكالية نابعة بالدرجة الأسـاس من الطبيعـة الخاصـة لعنصر الموسيقى عند اثتغاله في فضـاء

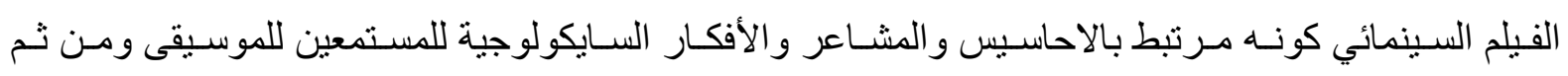
لمشاهدي الفيلم المتضمن لجمل موسيقية ربما تعد خصيصا للفيلم أو تتقل بشكل جاهز من حالتها السمفونية إلى وضعيتها السينمائية لكونها موسيقى تصورية تضاف للصور الفيلمية وليست مؤلفة خصيصة للفيلم كما هو حال

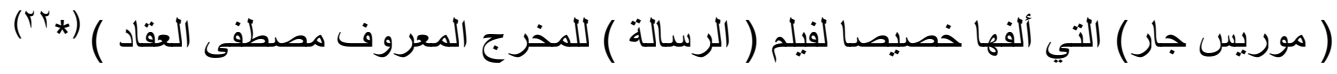
مؤشرات الإطار النظري اـ تتمو التضمينات السايكولوجية في عنصر الحوار بشكل أكبر من بقية العناصر الداخلة في تركيب الخطاب

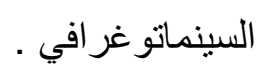

r- توظف التضمينات السايكولوجية سينمائية في بنية الفيلم الروائي على اساس ارتباطها بمرجعياتها العلمية . r- ترتبط التضمينات السايكولوجية بقصدية المخرج ورؤيته الإخر اجيـة من جهة ، وبالطبيعة النفسية للمتلقي

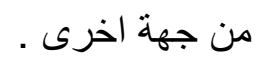

الاراسات السابقة

بعد اطلاع الباحث على الكثير من المصـادر والمؤلفات الموجودة في المكتبـة المركزيـة ومكتبـة كليـة الفنون الجميلة ومو اقع الانترنت وجد ان هنالك الكثير من الموضوعات المتعلقة بالاشتغالات السـايكولوجية في

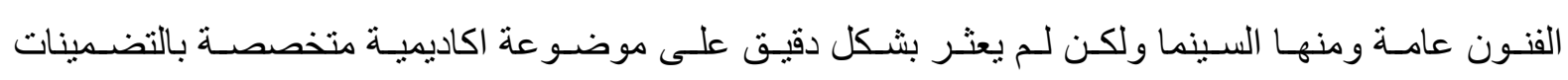
السايكولوجية في بنية الفيلم الروائي المعاصر ، ولذا تعد هذه الدراسـة متميزة نسبية عن غير هـا ممـا متوفر في في فئي المكتبات ، ومع ذلك نستطيع أن نذكر بعض الدراسات القريبة من تخصص هذه الدر اسة ومنها: 1 -در اسة الباحث فيصل لعيبي والموسومة ((اسس التوظيف السـايكولوجي لبناء الايهام البصري في الفيلم

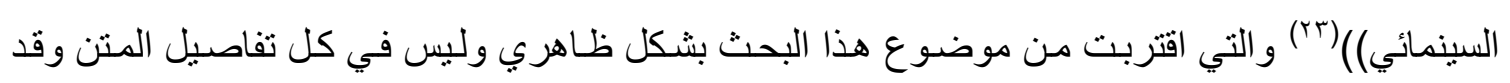
احتوت على خمسة فصول ، واستعانت بعدد من المصادر السـايكولوجية والسينمائية وكذلك اختارت أفلام

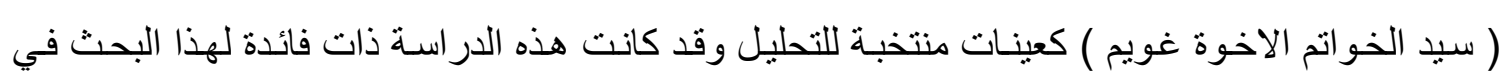

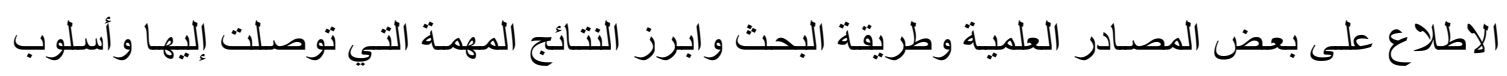
بحثها فضلا عن بعض الأفكار و المعلومات الواردة فيها . 


\section{الفمسل الثالث- اجـراءات البحسث}

اولا : منهج البحث

اعتمد الباحث المنهج الوصفي الذي ينطوي على التحليل في انجاز هذا البحث، ويعرف هذا المنهج بانهـ (وصف مـا هو كائن ويتضمن وصف الظـاهرة الراهنة وتركيبها و عملياتها والظروف السائدة وتسجيل ذلك

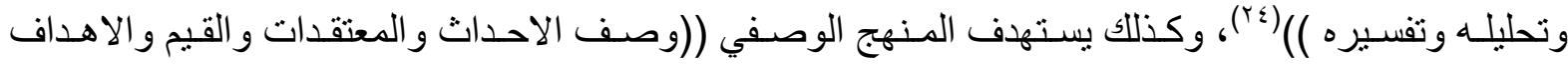
و انمـاط السـوك المختلفة)) (ror)، ويتلائم هذا المنهج وطبيعـة البحث فهو بيسعى لتحليل العينـة على وفق اداة واضحة ومحددة لتحقيق أهداف هذا البحث . ثانيا : مجتمع البحث

جميع الافلام السينمائية الروائية المعاصرة التي تعتمد على نغمات سايكولوجية . ثالثا : عينة البحث سيعتمد الباحث على اختيار فيلم (العطر) كعينة مختارة للتحليل بشكل قصدي وذلك

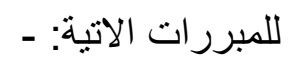

1 - اشتغال التضمينات السايكولوجية فيه بثكل واضح . r- يتمتع الفيلم بمو اصفات فنية عالية .

r- حصوله على جو ائز عديدة وكتب حوله الكثير من الدراسات النقدية .

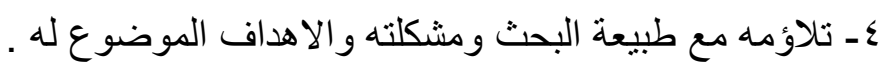
رابعا : اداة البحث

الغرض تحقيق الموضو عية لهذا البحث ، سيتم وضع واستخدام اداة يتم على وفق تحليل العينـة ، و عليه سيعتمد الباحث على مـا ورد من مؤشرات في الإطـار النظري كأداة للتحليل بعد عرضـها على لجنـة الخبراء والاخذ بملاحظاتهم وار ائهم العلمية واجر اء التعديلات على وفق ملاحظاتهم .

خامسا : وحدة التحليل اعتمد الباحث على وحدة التحليل المتمثلة باللقطة او المشـهد كونها وحدة قياس ثابتـة وواضحة المعالم ويمكن الاستعانة بها لتحليل التضمينات السايكولوجية المتو افرة في تلك المشاهد و اللقطات . التحليل ومناقشة العينات اسم القيلم / العطر انتاج / 9 / . إخر اج / توم تايكر بطولة / بين ويشاو ، داستن هوفمان

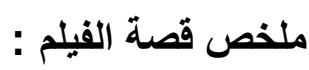


يتحدث الفيلم عن شخصية انسـانية غريبة عاثـت في القرن الثنامن عشر في مدينة بـاريس الفرنسية

تميزت بحاسـة شم قويـة جدا ممـا جعله مميزة في صناعة العطور ولكنها ايضـة ـ أي درجـة حساسيته للشتم جعلت منه قات؟ مجرمة للفتيات الجميلات التي يقتلهن ليس بدافع القتل أو الثهوة و إنما لأجل استخلاص (روح) العطر من أجسادهن الطريـة ، وهذه الثخصية تعـاني اصسلا من مرض سـايكولوجي فرضته حياة الفقر واليتم

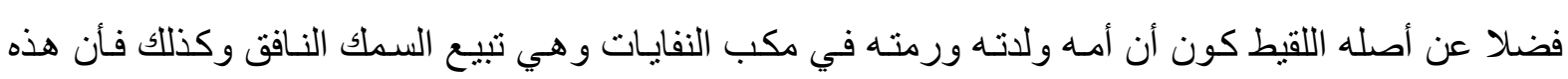
الثخصية التي تسمى (جون باتيست غرونوي) تصبح شخصية مشؤومة كونها تلقي بـالنحس الى كل من تلتقي بـه ثم تغادره وكما حدث للسيدة (غيلارد) صاحبة الميتم وكذلك صاحب المدبغة (غريمال) ومن ثم السيد بالديني) صاحب العطور وبعدها السيدة ارنولفي) وغير هم من الضحايا الذين مـا يلبثوا أن يلاقوا حتفهم بمجرد تعرفهم على شخصية (غرونوي) ومن ثم مغادرته لهم .

وبعد أن يتوصل (غرونوي) الى صنع عطره الاثير من اجساد ضحاياه يذهب الى مدينة (غراس) أنشـهر

مدينة فرنسية آنذاك في صنع العطور ، تتكاثر الاحتجاجات الثـعبية على كثرة حوادث القتل للفتيات الجميلات حتى يلقوا القبض عليه ولكنه يقوم برش العطر الذي صنعه وهو عطر الروح والحياة) عليهم فيسحر هم جميعا مسؤولين وشعب فيصبحون كالسكارى ويصبح في نظر هم قديسـة ويخلعون ملابسهم جميعا رجالا ونسـاء في مشهد طقوسي ساحر ويهرب منهم ويعود لمكانه الذي ولد فيه و هو مكب النفايات في في سوق السمك ويقرر التخلي عن العطر الذي صنعه و عندها يهجم عليه الناس فيلتهمونه بنوع من السادية البشرية ولا تبقى منه سوى ونى بضع قطع من قماش ملابسه دلالة تبخره وتساميه كالعطر . المؤشر الاول/ تنمو التضمينات السـايكولوجية في عنصر الحوار بثكل أكبر من بقية العناصر الاخلـة في تركيب الخطاب السينماتوغرافي . من المتفق عليه أن لعنصر الحوار في الافلام الروائية مسـاحة اشتغال واسعة ولذلك فان صـانع العمل فيل

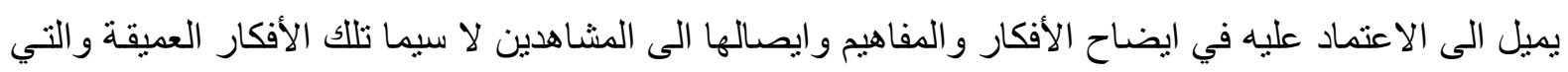

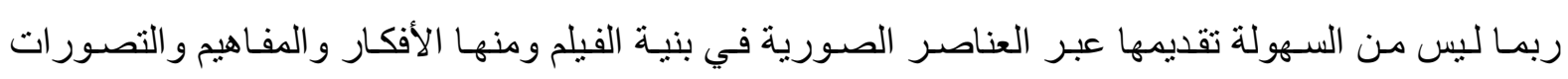
السايكولوجية ، ولذا نلاحظ أن هذا الفيلم الروائي المليء بالافكار السـايكولوجية تضمن عددا كبيرة منها عبر تضمينها من خلال عنصر الحوار ويمكن رصد ذلك من خلال مجموعة من الحوارات التي حفل بها الفيلم وكما يلي : * السيد (بالديني) : أن العطر هو روح الاشياء ... ان روح البشر هي عطرهم * السيد (بالايني : أن موت عشرة الاف زهرة ، تنتج لنا مقدارة من زيت العطر الاساسي . * الراوي: لأول مرة في حياته يدرك غرونوي انه ليس لايه رائحة خاصة بـه ، ادرك انه طو ال حياته لم يكن

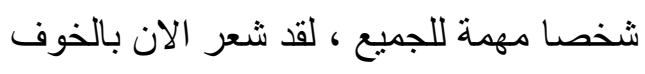
من نسيانه الذاتي وكأنه لم يكن موجودة . 
* السيد (باللديني): (بانزعـاج من نجـاح منافسـة باليسية) : مـا الذي جعلك نظن انني قد اهتم باختيار عطر

باليسية

* شنيه (بمكر) : انت محق ، انه ليس شيئا مميزة ، فالحقيقة أنها رائحة عادية ... جدا .

* شنيه : اجل ... تثمه في كل مكان من باريس هذه الايسام يـا سيدي ، عند كل زاويـة ، و الحقيقة اشتريت للك

عينة منه .

* السيد (بالديني) : كان عطر ا جميلا إلى أقصى حد وقويـة جدا لدرجـة انه في لحظة واحدة ظن كل شخص

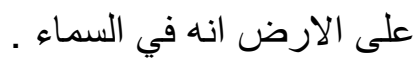
* غرونوي : - اريد ان اتعلم كيف احفظ رائحة وابقيها الى الابد . * الراوي : ـ كان ثــة أمر واحد يعجز العطر عن فعله ولم يستطع تحويله الى رجل يحب النـاس ويحبونـه كالاخرين ففكر في أن ذلك ليس مهما ، تبا للعالم و تبا للعطر ، تبأ لنفسه .

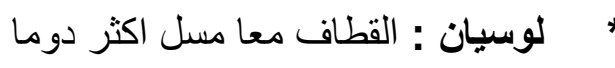

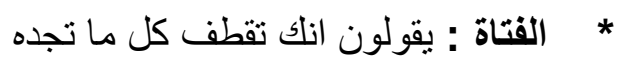
* السيد ريتشيز: لقد شاهدت ليلة الامس حلما سيئا وكأنك يا لور ا مقتولة . * لورا : ابي ... كل هذا بسبب حلم سيء.

أن هذه الحوارات المنتقاة من مشاهد الفيلم المختلفة و غير هـا من الحوارات الفيلمية بينت ماهية بعض الأفكـار و المفـاهيم و التصـور ات السـايكولوجية المتضــنة في ثنايـا الفيلم وعبـرت عـن طبيعـة الار هاصـات

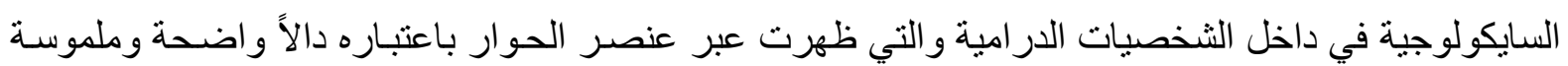

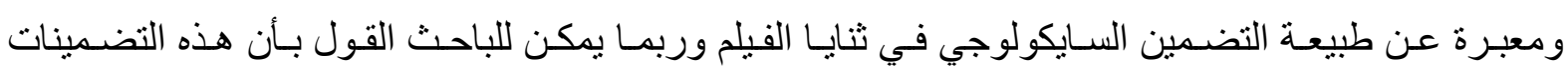
السايكولوجية المتمظهرة عبر الحوار قد لا يمكن تلمسها أو استيعابها من قبل المتلقي اذا مـا قدمت عبر عناصر أخرى وبنفس الوضوح و الكفاءة من قبل عنصر الحوار وهذا لا يعني أن بقية العناصر الفيلمية سواء كانت صورية أو صوتية (غير الحوار طبعا) غير قادرة على تقديم تضمينات سـيكولوجية عبر اشتغالاتها الدرامية ولكن يمكن أن تكون نسبة التوصيل عبر الحوار اكثر قليلا كونه يقدم معلومات و افكار واضحة ومباشرة المؤشر الثاني/ توظف التضمينات السـايكولوجية سينمائيا في بنية الفيلم الروائسي على اسـاس بمرجعياتها ارتباطها الفيلمية . لم تأت التضمينات السـايكولوجية في فيلم (العطر) من فر اغ و انمـا استندت و اعتمدت على مرجعيات

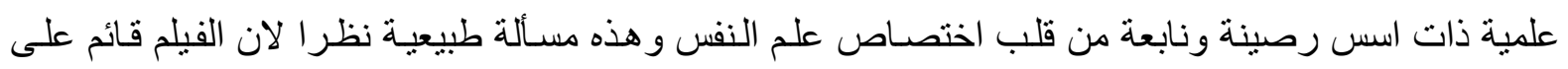
مفاهيم و افكار سايكولوجية بالاساس واغلب شخصياته الدر امية لاسيما الرئيسية منها مثل شخصية (غرونوي) و السيد (بالديني) هي شخصيات سـايكولوجية بامتيـاز لانها مصـابة بـأمر اض نفسية عديدة فضـلا عن طبيعـة 
تركيبها الدرامي المعتمد على المعطيات السايكولوجية التي قادت فعلها الدر اميـة داخل بنية قصـة الفيلم ، وكمـا سنلاحظ في بعض لقطات ومشاهد الفيلم وكالاتي :

* بمجرد التعرف على عنوان الفيلم (العطر) حتى يتبين لنا أن مضمون الفيلم هو سـايكولوجي كون العطر يرتبط دائما بالحالة السـايكولوجية للانسـان وبذلك فـان هذا المرتكز (عنوان الفيلم) يمثل تضمينة اولية للاتجـاه

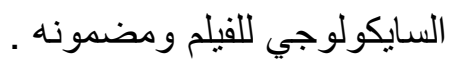

* موضوعة القتل المتكرر داخل أحداث ومشـاهد الفيلم هي قضية سـايكولوجية بالدرجـة الاسـاس فقد اثبتـت التجارب العلمية أن المجرمون هم غالبـة مرضى نفسيون بالدرجة الأولى وينفذون جر ائمهم لانهم يعانون من هن مشاكل و اضطر ابات سايكولوجية تؤدي بهم الى ارتكاب تلك الجرائم الثنيعة التي لايقدم عليها البشر الأسوياء و الأصحاء من الناحية النفسية .

* عانـت الثخصـية الرئيسـة (غرونـوي) مـن امـر اض سـايكولوجية جـرى تضـمينها سـينمائية و الدلالـة عليهـا صورية وصوتية ومن هذه الأمر اض النفسية هو الثعور بالنقص او ارتفاع مؤشر مركب النقص الحاصل في شخصيته نتيجة احساسه ومعرفته بأصله الوضيع كونه لقبط ويتيم ومنحوس وهذا مـا ثبت علمية في كثير من تجارب علماء النفس امثال (فرويد وآدلر ويونغ) و غير هم . * التفاوت الطبقي و المعاثي كان سبيا رئيسة في كثير من الاحداث و المواقف التي تبناهـا (غرونوي) وسـاعدت في بنـاءه السـايكولوجي المضـطرب والقلق حتـى أنـه وضـع نصـب عينــه في النهايـة هـي قتـل (لـورا) ابنـة الأرستقر اطي النبيل (ريتشيز) وترك جميع الضحايا الأخرى من الثابات الجميلات رغم سهولة قتلهن وصسوبة اللحاق ب (لور ا) و ابيها الهاربـان منـه وهذا النزوع السـايكولوجي للقتل و الاجر ام و السـادية لـه تجذير ات علميـة

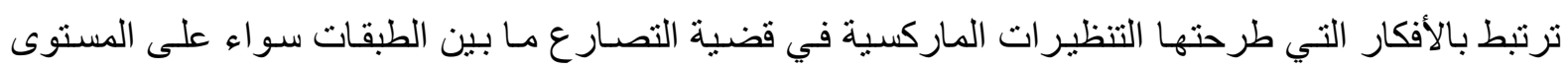
الفكري او الاقتصادي او السايكولوجي حيث أن شخصية (غرونوي) كانت حاقدة على كل رأسمالي او لئي * كذلك لاحظنا أن الكثير من التضمينات السـايكولوجية في لقطات ومشـاهد الفيلم كانت عبارة عن اسقاطات لحقائق علمية ونظريات سـايكولوجية معروفة وهو مـا اعطى لهذا الفيلم هذه القدرة التأثيريـة في المتلقي عبر

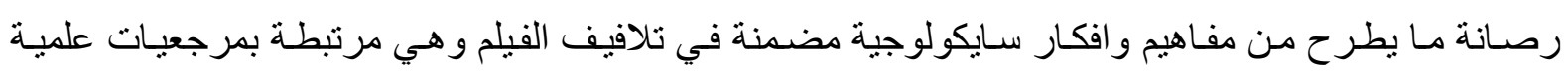
رصينة مثل المقولة الثهيرة للعالم النفساني (آدلر) و التي يذكر فيها أن كل مبدع هو انسان يعاني من مركب نقص معين سو اء كان هذا المركب او الاحساس بالنقص نفسي أم مادي أم عضوي وهو ما نجد اشتغاله واضحا في هذا بالديني) ل (غرونوي) ما يلي:- ((ان المصريين الأوائل يؤمنون بأن المرء يستطيع ابتكار عطر أصيل فعلا عبر زيادة نغمة اضافية ، رائحة واحدة نهائية تبرز وتسيطر على الاخرين ، تقول الأسطورة انه تم العثور ذات مرة على جرة في قبر الفرعون وحين تم فتحها خرج منها عطر بعد كل هذه اللَالاف من السنين وكان عطر ا جميلا وقوية لدرجة أنه في لحظة واحدة ظن كل شخص على الارض انه في السماء وان بإمكانه تمبيز ( r ( ) رائحة، اما الر ائحة (r ( ) وهي الر ائحة الحيوية فلا يمكن تحديدها ابدا)). 
و هكذا يمكن تلمس العديد من التضمينات السايكولوجية في الفيلم والتي ترتبط بمرجعيات علمية سو اء في ميدان علم النفس او في ميادين اخرى كالبايولوجيا او الفسيولوجيا او في التأريخ او في الفلسفة او في الفن عمومأ. المؤشر الثالث / ترتبط التضمينات السـايكولوجية بقصدية المخرج وروئيته الاخراجية من جهة ، وبالطبيعة النفسية للمتلقي من جهة اخرى .

يقول اندرو دادلي في كتابه نظريات الفيلم الكبرى ما مفاده أن كل مـا يظهر في الفيلم على الثانــة هو علامة و هو مقصود و هو ما ينطبق تماما هنا على قضية التضمينات السايكولوجية في بنيـة الفيلم المختار كعينة (العطر) فيمكن القول بأن جميع الأفكار و التصور ات و الاشتغالات السـايكولوجية المتو افرة في الفيلم انما ترتبط نسيجية بقصدية صانع العمل (المخرج) ومن قبله المؤلف سواء كان الكاتب الأصلي او كاتب السيناريو وتظهر بـر هذه القصدية بشكل واضـح في الرؤيـة الإخر اجية للمخرج الذي يضـع التشكيل النهائي للموجودات و العناصر و المرئيات وجميع التفاصيل التي تظهر على شاثـة العرض السينمائي ويحاول المخرج هنا ايضـا أن يوصل هذه الآليات و الكيفيات في التضمين السـايكولوجي وطريقة إخر اجها وتقديمها صورية للمتلقي و التحاور مـع طبيعة تر اكيبة السايكولوجية ومعطياتها وبالتالي التأثير فية من الناحية النفسية وتعميق الاحساس لديه بمـا يطرح فيلمية ودفعه للتو اصل نفسية وسينمائية مع الفيلم وهذا جزء من ستر اتيجية أي مخرج او اي فيلم ينشد النجاح و التأثثر في مشاهديه ويمكن رصد وتثخيص اكثر من رؤيسة اخر اجية ذات قصدية واضحة في التضمين السـايكولوجي

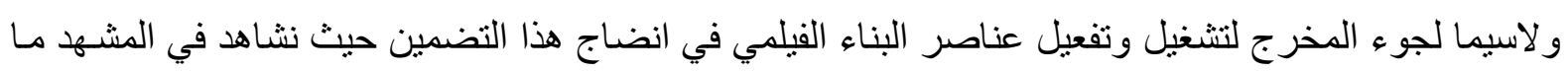
بعد الافتتاحي لفيلم (العطر) أن المشهد برمته عبارة عن ظلام شبه تام عدا بقعة ضوء تسقط على انف شخصية

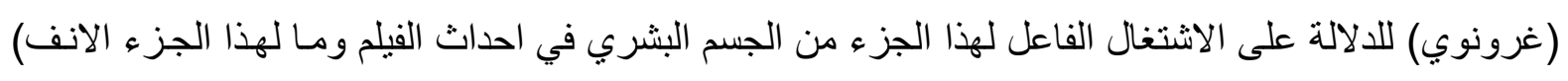
من دلالة سايكولوجية كونها ترتبط (في الفيلم بموضو عة (شم العطر) وهي حالة بايو اسـايكولوجية وصساحب

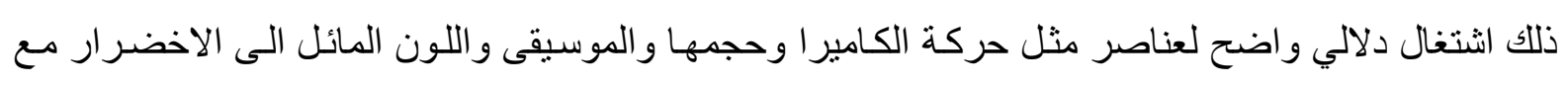

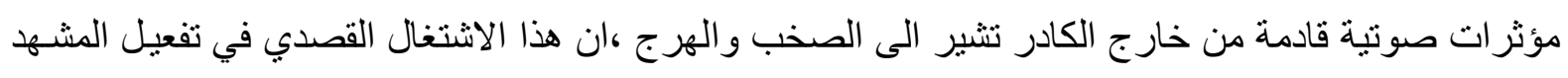

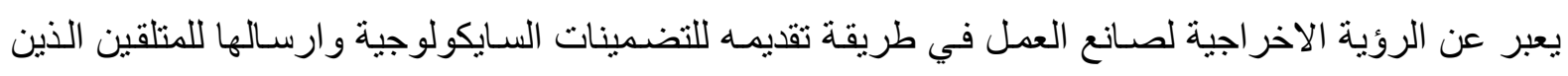
يتطلب مـنهم بالضـرورة ابـداء ردود افعـال (غيـر ملحوظـة طبعـا) تتناسـب مـع امكانـاتهم المعرفيـة و الثقافيـة ومرجعياتهم الفكرية وطبيعة التركيب السايكولوجي لكل منهم على إنفراد و على المستوى الجمعي احيانا . كما يمكن رصد اشتغال مميز للرؤية الإخر اجية وقصديتها في تقديم ومعالجة التضمينات السـايكولوجية في بنية الفيلم ومحاولة صانع العمل للتأثير في البناء السايكولوجي والتركيب الذهني للمتلقي ومحاولة التأثير فيه عبر مجموعـة من الرموز والدلالات والاحسالات المباثـرة أو غير المباثـرة حيث نرصد في المشهـ مـا قبل الختامي حيث الجموع الغفيرة وهي تحاول انز ال القصاص بالمجرم (غرونوي) بعد القاء القبض عليه و عندها

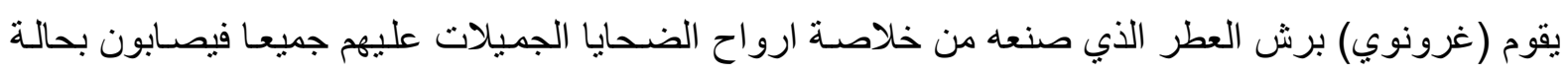

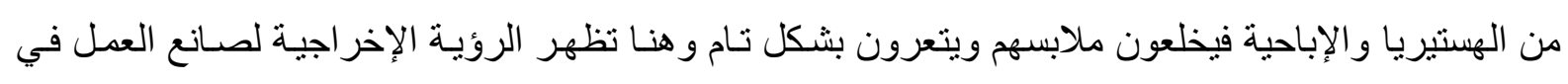
بيان و ايضـاح هذا الفعل السـايكولوجي وتضمينه في بنيـة فيلم العطر وهو مـا يعد مؤشر ا على رؤيـة اخر اجيـة 
معينة يقصد منها المخرج بيان التأثثر الكبير الذي مارسه (غرونوي) على الجميع بمـا فيهم الثـرطة والقساوسـة وأهالي الضحايا الذين قتلهم وصنع من اجسادهن عطرة خالدة ومثاليـة ولم يسبقه إليه أحد حتى ظن النـاس أنسه نبي او قسيس او رجل صالح او حتى (اله) وهذا الشعور ربما يصل الى المتلقي الذي يتفاجأ بالقدرة الهائلة التي

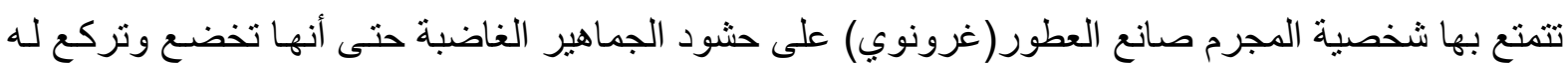
وتمارس طقوسة إباحية غريبة وشاذة ، وهذا ما يؤكده علماء النفس بأن بعض الانفعالات والسلوكيات و الافعال تنتقل باللاشعور او اللاوعي من شخص إلى آخر بطريقة لا ارادية وهو مـا يفعله الفيلم السينمائي احيانـا وينتقل التأثير والمشاعر عبر رؤية اخر اجية منميزة من الثخصيات الفيلمية إلى الثخصيات الو اقعيـة المتلقية للمشـاهدة

الطقسية السينمائية .

النتشائج:-

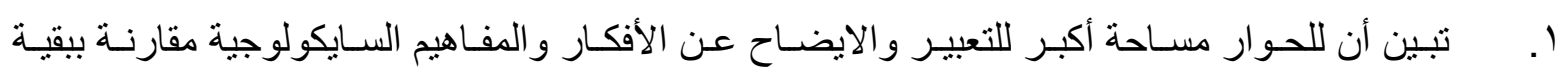

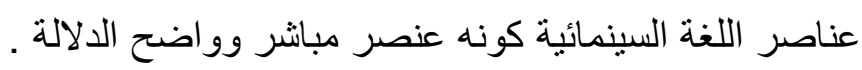
r. تم رصد أن التضمينات السـايكولوجية المتو افرة في الفيلم قد تم توظيفها صسورية وصوتية بناء على بعض المعطيات والمرتكز ات ذات الأساس العلمي المعتمد في مبادئ ونظريات علم النفس . r. لوحظ أن التضـينات السـايكولوجية مرتبطـة بشكل مباثـر أو غير مباثـر بالرؤيـة الاخر اجيـة لصـانع العمل وقصديته في التناول و المعالجة وهي مرتبطة فكرية وسايكولوجية بالتركيب النفسي والذهني لمتلقي الفيلم ع. ساهمت بعض عناصر اللغة السينمائية في ايضـاح وتقديم التضمينات السـايكولوجية عبر المسـاعدة في

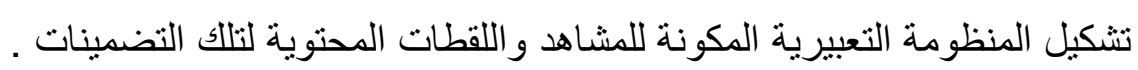
•. للمتلقي دور كبير في استنطاق واستيعاب التضمينات السايكولجية التي تم تقديمها سينمائية عبر التفاعل و التو اصل سايكولوجية وفكرية مع ما طرحه الفيلم من تضمينات و افكار وتصور ات سايكولوجية .

\section{| الاسمنتماجمات}

ا. عندما يتم تقديم موضو عات ذات ميول تجريدية ونظرية نسبية يتم الاعتماد على اكثر العناصر الفيلمية وضوحة وسهولة لتقديم تللك الأفكار ويأتي الحوار في مقدمة تللك العناصر الموظفة للتقديم . r. . من الصعب على التضمينات السـايكولوجية أن تقدم اعتباطية في ثنايـا الفيلم السينمائي دون الاعتمـاد على مرجعيات علمية تعطيها صفة التأثير والمنطقية والثبوتية في الاقناع . r. تتدخل الرؤى الاخر اجية لصانعي الأعمال الإبداعية في تشكيل منظومة العرض و التقديم لأجل صياغة وبلورة افضل طريقة ممكنة للتأثير في المتلقي ودفعه للاستمر ار و التو اصل مع عالم الفيلم والتفاعل معه بشكل ايجابي

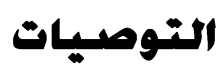
ا . ضرورة توسيع حجم المقررات الدر اسية المعنية بالدراسات السايكولوجية في المناهج الدراسية الأولية والعليا .

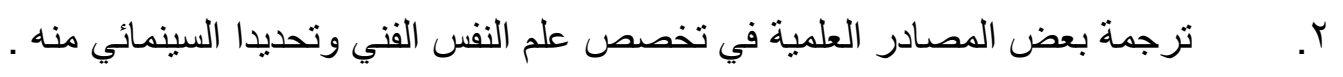


r. اقامة مكتبة صورية في قسم السينما والتلفزيون تتضمن على اهم الاصدار ات الفيلميـة التي تحتوي مو اضيع سايكولوجية ذات اسس ونظريات علمية .

المثمترحاث

'. دراسة المفاهيم السايكولوجية الحديثة و اشتغالاتها في الفيلم الروائي المعاصر . . r. . دراسة الاشتغالات السايكولوجية في الثخصيات الدرامية المقدمة في المسلسـلات التلفزيونيـة العر اقيـة

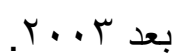

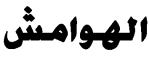

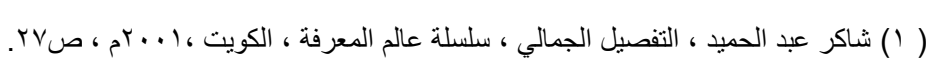

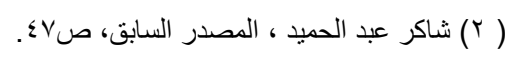

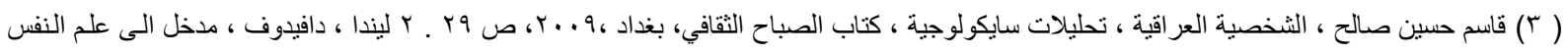

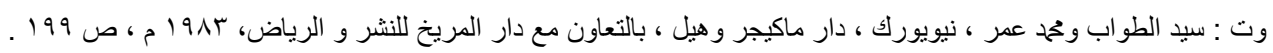

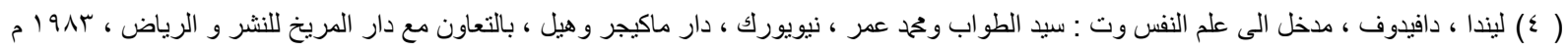

$$
\begin{aligned}
& \text { ، ص } 199 .
\end{aligned}
$$

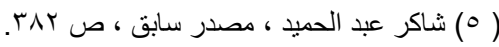

$$
\begin{aligned}
& \text { (7 (7) ينظر وي دي جانيتي، مصدر سابق، ص79. } \\
& \text { (V) نعمان بوقرة، المصطلحات الاساسية في لسانيات النص وتحليل الخطاب، عالم الكتب الحديث، عمان، 9 . . Y، صع } 9 .
\end{aligned}
$$

( ) علي إسماعيل ، أسلوبية البناء الفيلمي في أفلام جيمس كاميرون ، رسالة ماجستير غير منشورة ، جامعة بغداد ، كلية الفنون الجميلة ، ـ ا ـr، ص.

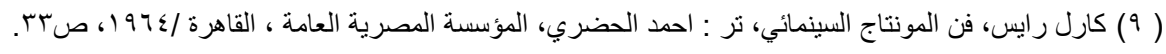

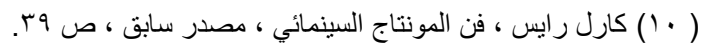

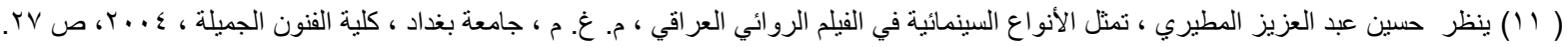

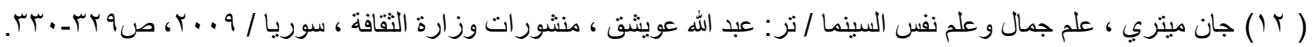

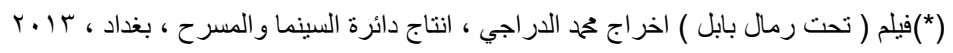

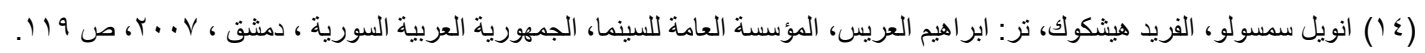

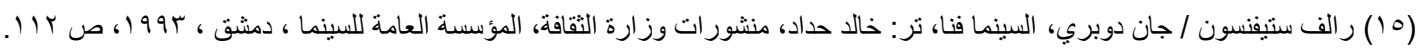

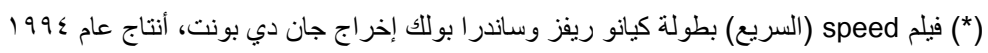

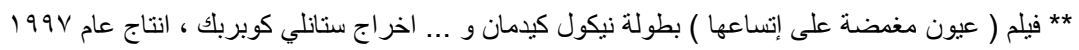
r. - - المصدر السابق نفسه ، ص (IV)

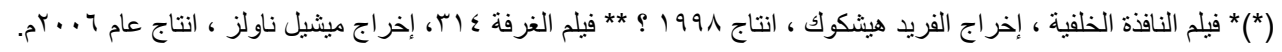

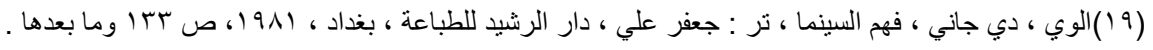

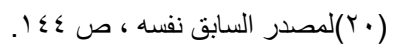

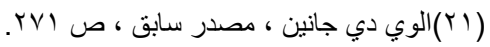

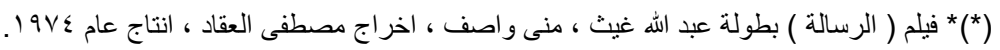

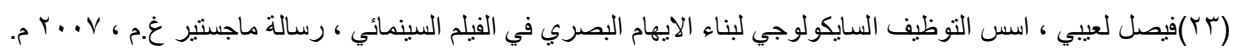




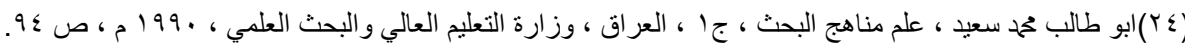

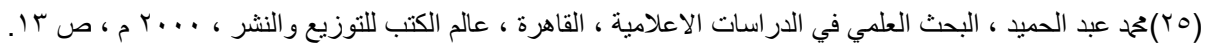

القران الكريم

او لا : المصادر من الكتب العربية والمترجمة : الكمربم

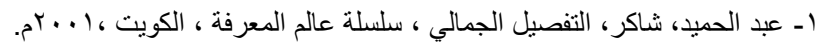

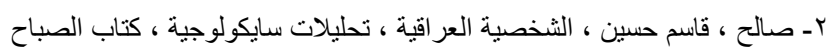

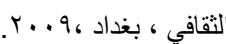

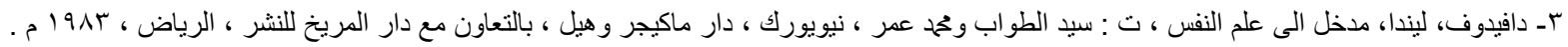

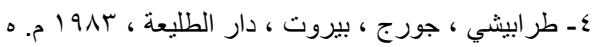

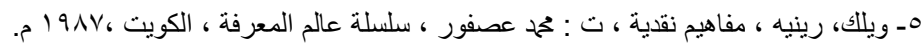

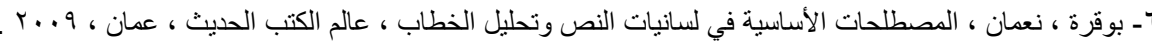

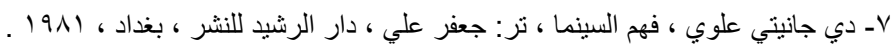

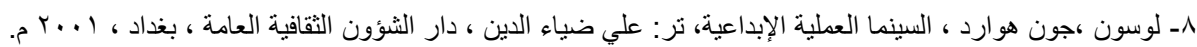

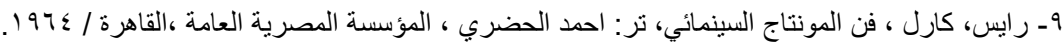

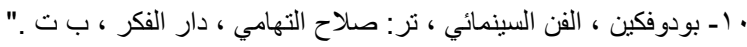

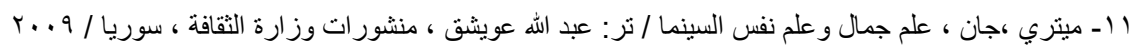

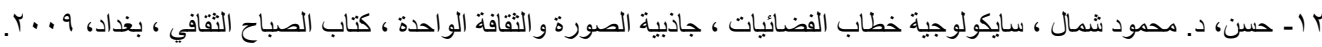

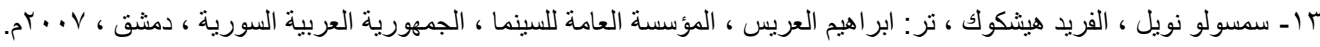

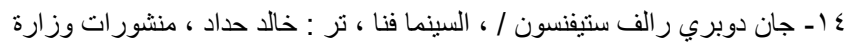

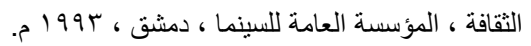

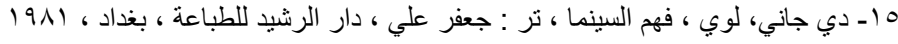

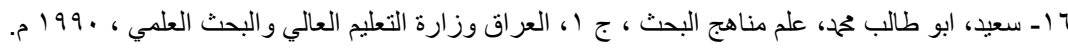

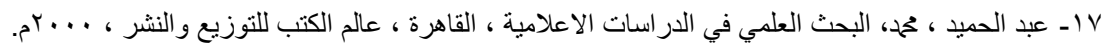

ثانيا : المصادر من الرسائل والاطاريح :

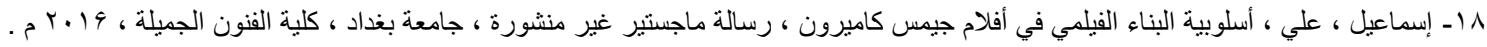

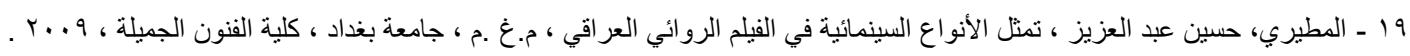

ثالثا : المصادر من الكتب الاجنبية : ohio, Columbus ,Charles, merrill, $19 \vee \varepsilon$, p. $\vee$.. .- Cooper, john D.Measurment \& analysis of behavioral techniques, رابعا : المصادر من الافلام :

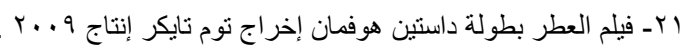

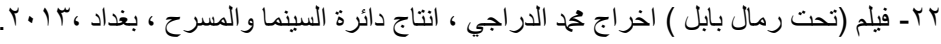

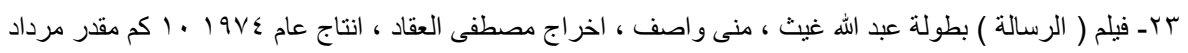

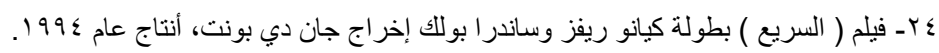

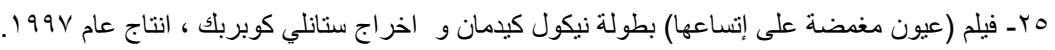

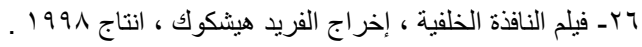

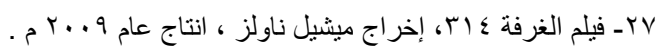

